Article

\title{
Synthesis and Antimicrobial Evaluation of a New Series of Heterocyclic Systems Bearing a Benzosuberone Scaffold
}

\author{
Osama I. Abd El-Salam ${ }^{1}$, Ali S. Alsayed ${ }^{2}$, Korany A. Ali ${ }^{1}$, Ahmed A. Abd Elwahab ${ }^{1}$, \\ Abd El-Galil E. Amr ${ }^{3, *}$ and Hassan M. Awad 4,5 \\ Received: 11 September 2015 ; Accepted: 4 November 2015 ; Published: 16 November 2015 \\ Academic Editor: Wim Dehaen \\ 1 Applied Organic Chemistry Department, National Research Centre, Dokki, Giza 12622, Egypt; \\ osielsalam@gmail.com (O.I.A.E.-S.); kornykhlil@gmail.com (K.A.A.); \\ ahmed_abdelsalam@hotmail.com (A.A.A.E.) \\ 2 Chemistry Department, Al-Azhar University, Nasr City, Cairo 1435, Egypt; ali.sief1980@hotmail.com \\ 3 Department of Pharmaceutical Chemistry, Drug Exploration \& Development Chair, College of Pharmacy, \\ King Saud University, Riyadh 11451, Saudi Arabia \\ 4 Chemistry of Natural and Microbial Products Department, Pharmaceutical Industries Division, \\ National Research Centre, 33 El Buhouth St. (Former El Tahrir St.), Dokki, Giza 12622, Egypt; \\ awadmhassan@yahoo.com \\ 5 Deanship of Preparatory Year, Al jouf University, AL Jouf, Skaka 2014, Saudi Arabia \\ * Correspondence: aeamr1963@yahoo.com or aamr@ksu.edu.sa; Tel.: +966-565-148-750
}

\begin{abstract}
A series of novel benzosuberone derivatives were synthesized and evaluated as antimicrobial agents by using substituted benzosuberone derivatives $\mathbf{1 a}, \mathbf{b}$ as starting materials. Treatment of $\mathbf{1} \mathbf{a}, \mathbf{b}$ with phenyl isothiocyanate in dimethylformamide was followed by treatment with cold $\mathrm{HCl}$ solution to afford the thioamides $\mathbf{4 a}, \mathbf{b}$, which was reacted with methyl iodide to obtain methylated products $\mathbf{5 a}, \mathbf{b}$. Cyclocondensation of $\mathbf{4 a , b}$ with chloroacetone $\mathbf{6}$ and phenacyl chloride 7 gave the corresponding thiophene derivatives $\mathbf{9 a - c}$. Reaction of $\mathbf{4 a}, \mathbf{b}$ with $\mathrm{C}$-acetyl- $\mathrm{N}$-arylhydrazonoyl chlorides $\mathbf{1 4} \mathbf{a}$ and $\mathbf{1 4} \mathbf{b}$ in boiling EtOH in the presence of triethylamine, afforded the corresponding 1,3,4-thiadiazoline derivatives $\mathbf{1 6 a}-\mathbf{d}$. The thioamides $\mathbf{4 a}, \mathbf{b}$ were reacted with C-ethoxycarbonyl- $N$-arylhydrazonoyl chlorides 18a, $\mathbf{b}$ which afforded 1,3,4-thiadiazoline derivatives 19a-d. The benzosuberones $1 \mathbf{a}, \mathbf{b}$ were treated with 3-mercaptopropanoic acid to give compounds 21a,b, which were cyclized to tricyclic thiopyran-4(5H)-one derivatives 22a,b. The latter compounds 22a,b were reacted with 3-mercaptopropanoic acid to give compounds $\mathbf{2 3 a} \mathbf{a}, \mathbf{b}$, which were cyclized tetracyclic ring systems $\mathbf{2 4 a , b}$. Finally, compounds $\mathbf{2 4 a}$, $\mathbf{b}$ were oxidized using hydrogen peroxide under reflux conditions to afford the oxidized form of the novel tetracyclic heterogeneous ring systems $\mathbf{2 5 a} \mathbf{a} \mathbf{b}$. The newly synthesized compounds were screened for antimicrobial activities. The structures of new compounds were characterized by ${ }^{1} \mathrm{H}-\mathrm{NMR}$, ${ }^{13} \mathrm{C}-\mathrm{NMR}, \mathrm{IR}$, and EI-MS.
\end{abstract}

Keywords: benzosuberone; nitro-benzosuberone; thioamide; thiophene; thiadiazole; antimicrobial activity

\section{Introduction}

Thiazolopyrimidine derivatives were studied as potential drug candidates with biological activities [1]. In a previous work, we reported that certain of our newly substituted heterocyclic compounds exhibited androgen receptor antagonists and anticancer activities [2,3]. Also, substituted and condensed cycloalkanones derivatives are of special interest for the preparation of potentially 
bioactive compounds as they possess anti-inflammatory, anti-convulsant, anti-pyretic, anti-tumor, and anti-ulcer activities [4]. Benzosuberone moiety is the main scaffold in tricyclic antidepressant drugs such as noxiptiline and amitriptyline (the analogues of imipramine), which mostly affect the central nervous systems $[5,6]$. On the other hand, heterocyclic sulfur compounds are of special interest in modern medicinal chemistry. For example, thiophene and thiadiazole derivatives are a well-known class of biologically active basic compounds for a large number of new drugs [7-9]. In view of these observations and in continuation of our current interest in the synthesis of poly-substituted heterocycles for biological evaluations [10-14], the present work was planned to prepare some new benzosuberone derivatives bearing thiadiazole and thiophene moiety, in addition to synthesis of new tricyclic and tetracyclic compounds bearing the benzosuberone scaffold. The newly synthesized compounds were investigated as antimicrobial agents.

\section{Results and Discussion}

\subsection{Chemistry}

Thioamide and thioanalide intermediates are considered to be a category of versatile intermediates that provide building blocks in the synthesis of poly-substituted thiophene and thiadiazole derivatives $[15,16]$. Preparation of benzosuberone derivatives substituted with thioamide and thioanalide was achieved by the treatment of the benzosuberone derivatives $\mathbf{1} \mathbf{a}, \mathbf{b}$ with phenyl isothiocyanate in dimethylformamide, in the presence of potassium hydroxide, followed by treatment with cold $\mathrm{HCl}$ solution to afford the thioamide derivatives $4 \mathbf{a}, \mathbf{b}$ with $81 \%$ and $79 \%$ yields, respectively (Scheme 1). The ${ }^{1} \mathrm{H}-\mathrm{NMR}$ spectrum of the thioamide $4 \mathbf{a}$ as an example, revealed the presence of multiple signals at $1.90 \mathrm{ppm}$ and two triplet signals $2.41-3.20 \mathrm{ppm}$ characteristic for $3 \mathrm{CH}_{2}$ protons, in addition to a broad signal at $11.50 \mathrm{ppm}$ due to $\mathrm{NH}$ proton. The mass spectrum of compound $4 \mathbf{a}$ revealed a peak at $\mathrm{m} / \mathrm{z} 295$ corresponding to its molecular ion peak. Treatment of the thioamide derivatives $\mathbf{4 a}, \mathbf{b}$ with methyl iodide in EtONa solution afforded the methylated products $\mathbf{5 a}, \mathbf{b}$ (Scheme 1). The ${ }^{1} \mathrm{H}-\mathrm{NMR}$ spectrum of compound 5a displayed a new singlet signal at $3.08 \mathrm{ppm}$ characteristic for $S$-methyl group.

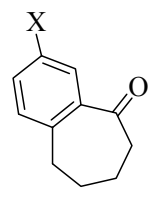

1a,b
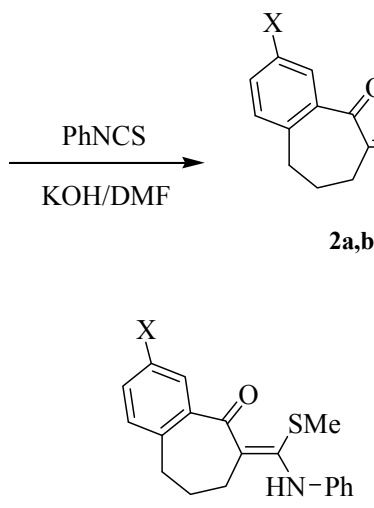

5a,b

$\mathbf{2 a}, \mathbf{b}$
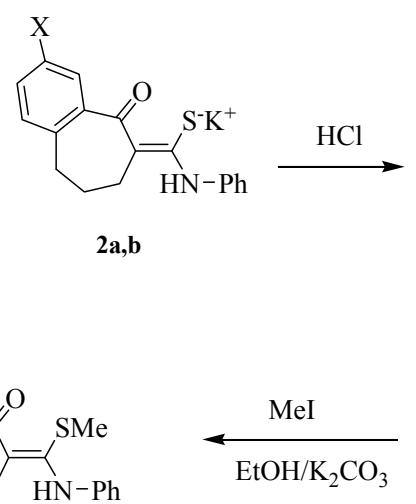

$\mathrm{EtOH} / \mathrm{K}_{2} \mathrm{CO}_{3}$

$\mathbf{a}, \mathrm{X}=\mathrm{H} ; \mathbf{b}, \mathrm{X}=\mathrm{NO}_{2}$
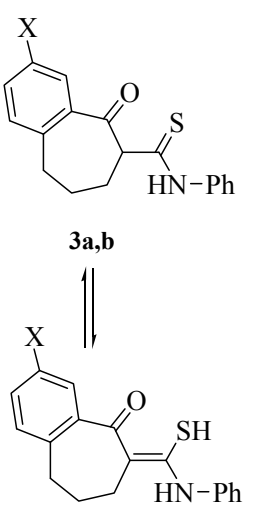

$4 a, b$

Scheme 1. Synthetic routes for compounds $\mathbf{4 a}, \mathbf{b}$ and $\mathbf{5 a}, \mathbf{b}$.

Cyclocondensation of the thioamide derivatives $4 \mathrm{a}$ and $4 \mathrm{~b}$ with chloroacetone 6 and phenacyl chloride 7 in refluxing $\mathrm{EtOH}$, in the presence of a catalytic amount of triethylamine furnished, in each case, was only one isolated product. The identities of the isolated products were assigned as the thiophene derivatives 9a-c rather than the isomeric 1,3-thiazoles $\mathbf{1 0}$ (Method A, Scheme 2), on the basis of their spectral data. The IR spectrum of compound $\mathbf{9 b}$, as an example of the synthesized compounds, showed the presence of $\mathrm{NH}$ and carbonyl bands at 3428 and $1654 \mathrm{~cm}^{-1}$, respectively. 
Moreover, the ${ }^{1} \mathrm{H}-\mathrm{NMR}$ spectrum of compound $9 \mathbf{b}$, revealed multiplets at 1.72 and $2.35-2.59 \mathrm{ppm}$ corresponding to $3 \mathrm{CH}_{2}$ groups, in addition to signals at 3.30 and $9.53 \mathrm{ppm}$ corresponding to $\mathrm{CH}_{3}$ and $\mathrm{NH}$ protons, respectively. Compound $9 \mathrm{c}$ was also prepared using thioamide derivative $4 \mathbf{a}$ and phenacyl chloride $\mathbf{7 b}$ in DMF in the presence of potassium carbonate at room temperature (Method B, Scheme 2). The product $9 \mathrm{c}$ from the later method was identical in all respects with the previously obtained authentic sample $9 \mathrm{c}$.

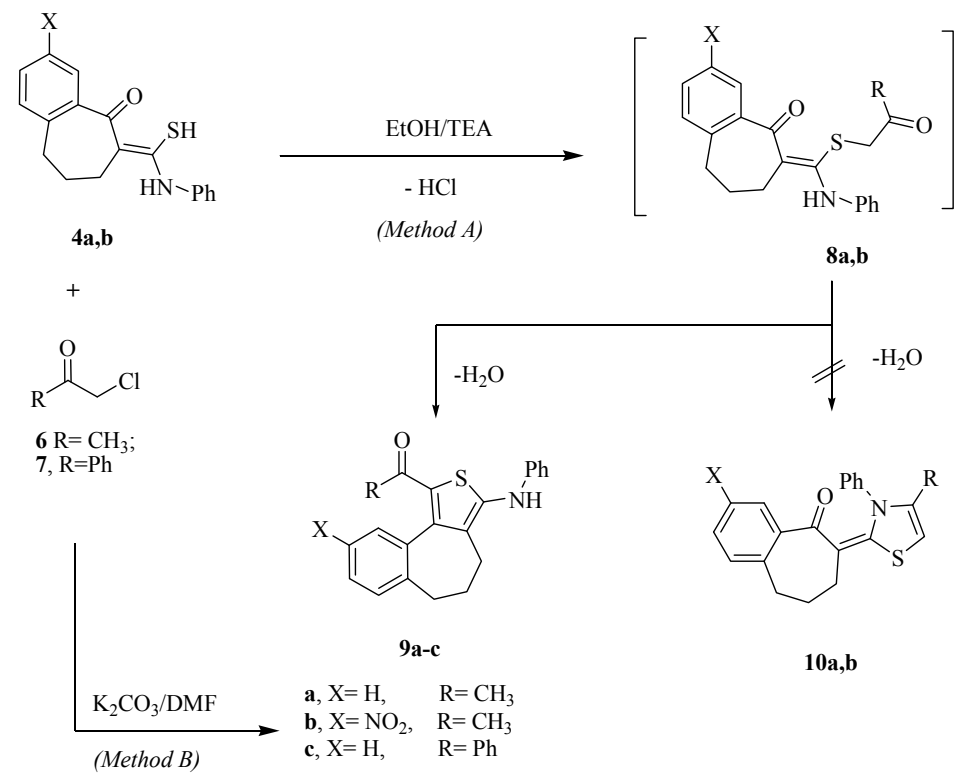

Scheme 2. Synthetic routes for compounds $9 a-c$.

Further evidence for the proposed structure of compound 9a was obtained by an independent synthesis via treatment of thioamide derivative $4 \mathbf{a}$ with 3-chloroacetylacetone in refluxing $\mathrm{EtOH}$, in the presence of a catalytic amount of triethylamine. The obtained product $9 \mathrm{a}$ identical in all respects (mp, TLC, and spectra) with that obtained from the reaction of the thioamide derivative 4a with chloroacetone. A reasonable mechanism of the latter reaction is outlined in Scheme 3, the addition of the haloketone to $\mathbf{4 a}$ with the elimination of $\mathrm{HCl}$ gave $\mathbf{1 1}$ followed by intramolecular cyclization to give 12, which under the effect of hydronium ion gave 13 and elimination of acetic acid gave $\mathbf{9 a}$.

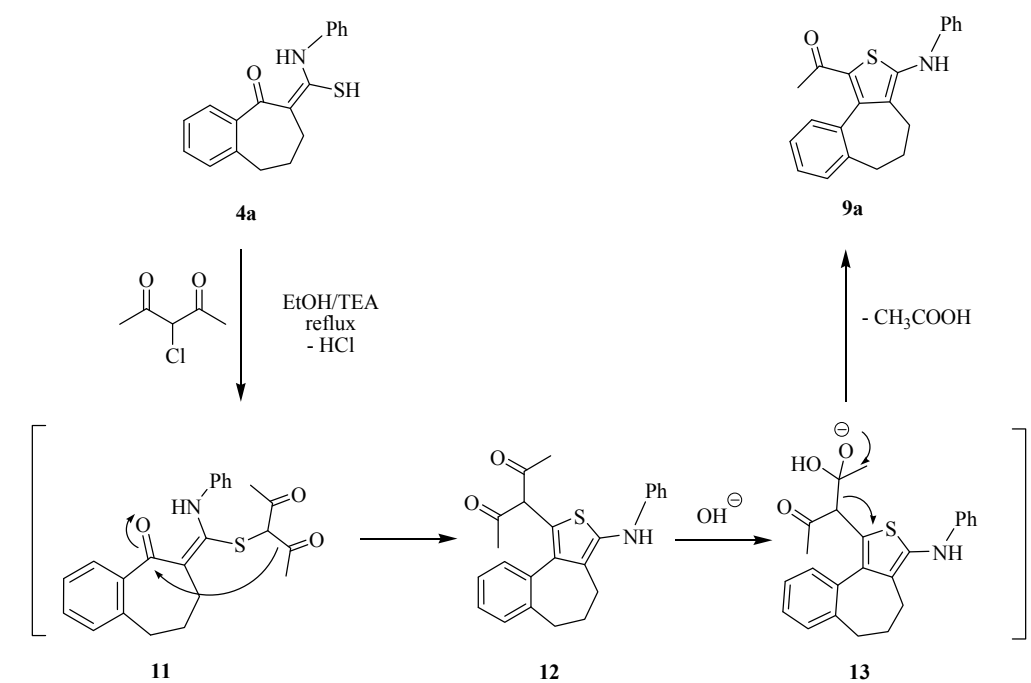

Scheme 3. Mechanism of formation compound 9a. 
We have investigated the behavior of the thioamide derivatives $4 \mathbf{a}, \mathbf{b}$ toward hydrazonoyl halide derivatives to prompt our synthetic strategy toward new heterocyclic systems attached to the benzo-suberone scaffold. Thus, treatment of the thioamide derivatives $4 \mathbf{a}$ and $4 \mathbf{b}$ with $C$-acetyl- $N$-arylhydrazonoyl chlorides $\mathbf{1 4 a}$ and $\mathbf{1 4 b}$ in boiling EtOH in the presences of triethylamine, afforded in each case only one isolated product. The identities of the isolated products were assigned as the 1,3,4-thiadiazoline derivatives $\mathbf{1 6} \mathbf{a}-\mathbf{d}$ rather than the arylhydrazono-thiazole derivative $\mathbf{1 7}$ on the basis of their spectroscopic data (Scheme 4). For example, compound 16c showed characteristic IR bands at $1671,1653 \mathrm{~cm}^{-1}$ due to two carbonyl groups. The ${ }^{1} \mathrm{H}-\mathrm{NMR}$ spectrum of $16 \mathrm{c}$ revealed multiplets at $1.53,2.38-2.46 \mathrm{ppm}$ due to the protons of $3 \mathrm{CH}_{2}$ groups and signal at 3.43 ppm due to the acetyl protons. In addition, its mass spectrum revealed a peak at $m / z 380$ corresponding to its molecular ion peak.

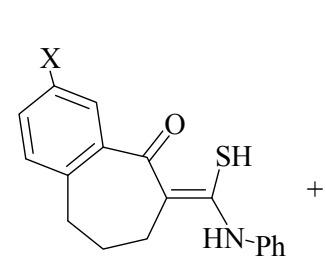

$4 \mathbf{a}, \mathbf{b}$

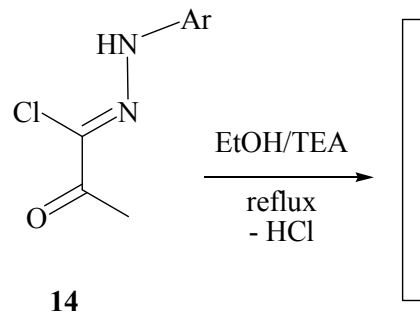

14

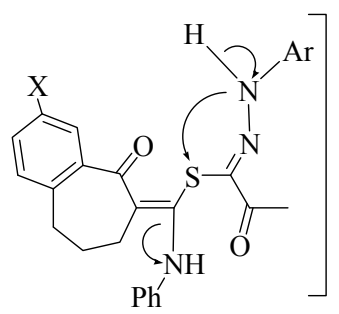

15

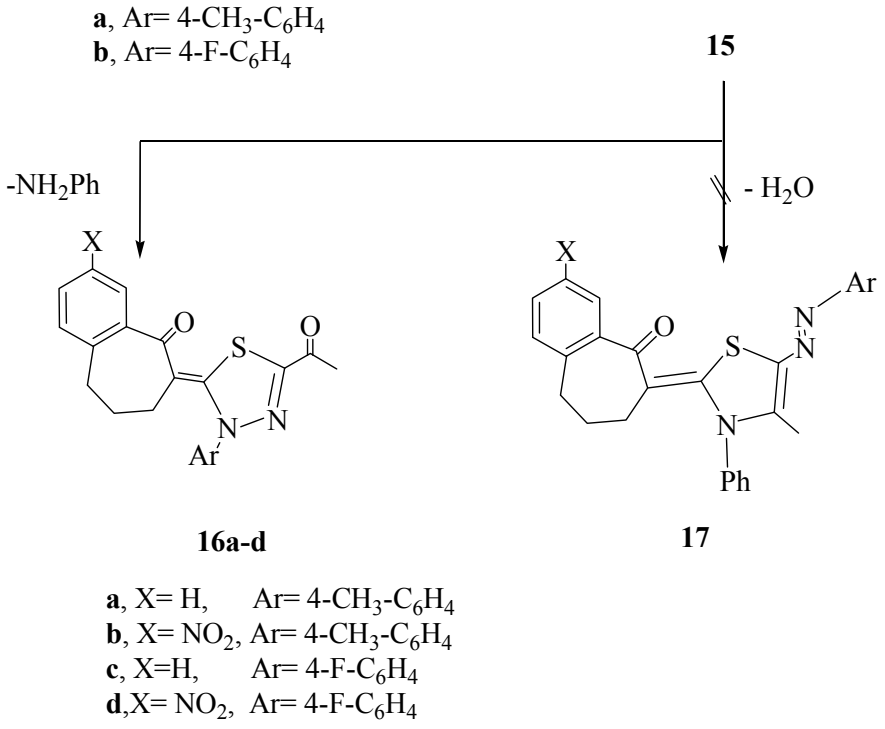

Scheme 4. Synthetic routes for compounds $16 a-d$.

In a similar manner, the thioamides $\mathbf{4 a}$ and $\mathbf{4 b}$ were reacted with C-ethoxycarbonyl$N$-arylhydrazonoyl chlorides $\mathbf{1 8 a}$ and $\mathbf{1 8 b}$ under the same reaction condition and afforded 1,3,4-thiadiazoline derivatives 19a- $\mathbf{d}$ rather than the thiazole-4-one derivative $\mathbf{2 0}$ on the basis of their spectroscopic data (Scheme 5). For example, compound 19a showed characteristic IR bands at 1718, $1675 \mathrm{~cm}^{-1}$ due to $2 \mathrm{C}=\mathrm{O}$ groups. The ${ }^{1} \mathrm{H}-\mathrm{NMR}$ spectrum of 19a was revealed triplet and quartet signals at 1.71 and 4.20 because of methyl and methylene of the ester group, in addition to multiplets in the region 2.36-2.8 ppm due to the protons of $3 \mathrm{CH}_{2}$ groups. The mass spectrum of compound 19a revealed a peak at $m / z 392$ corresponding to its molecular ion.

The reaction of $\mathbf{1 a}, \mathbf{b}$ with 3-mercaptopropanoic acid in refluxing benzene, in the presence of 4-toluenesulfonic acid (PTSA), results in compounds $\mathbf{2 1 a}, \mathbf{b}$ which undergo interamolecular cyclization under reflux temperature using phosphorus pentoxide to afford the novel tricyclic thiopyran-4(5H)-one derivatives $\mathbf{2 2 a} \mathbf{a}, \mathbf{b}$ (Scheme 6). The structures of the latter products were established on the basis of their elemental analysis and spectral data. 
<smiles>[X]c1ccc2c(c1)C(=O)/C(=C(/S)Nc1ccccc1)CCC2</smiles><smiles>CCOC(=O)/C(Cl)=N\N[Al]</smiles>

18

a, $\mathrm{Ar}=\mathrm{C}_{6} \mathrm{H}_{5}$

b, $\mathrm{Ar}=\mathrm{C}_{6} \mathrm{H}_{4} \mathrm{CH}_{3}-4$<smiles>[X]c1ccc2c(c1)C(=O)c1c(CCCc3ccc([Y10])s3)c(nn1[Al])C(=O)CC2</smiles>

a, $\mathrm{X}=\mathrm{H}, \quad \mathrm{Ar}=\mathrm{C}_{6} \mathrm{H}_{5}$ b, $\mathrm{X}=\mathrm{NO}_{2}, \mathrm{Ar}=\mathrm{C}_{6} \mathrm{H}_{5}$ c, $\mathrm{X}=\mathrm{H}, \quad \mathrm{Ar}=\mathrm{C}_{6} \mathrm{H}_{4} \mathrm{CH}_{3}-4$ d, $\mathrm{X}=\mathrm{NO}_{2}, \mathrm{Ar}=\mathrm{C}_{6} \mathrm{H}_{4} \mathrm{CH}_{3}-4$<smiles>[X]c1ccc2c(c1)C(=O)/C(=C1/S/C(=N\N[Al])C(=O)N1c1ccccc1)CCC2</smiles>

20

Scheme 5. Synthetic route for compounds $19 a-d$.

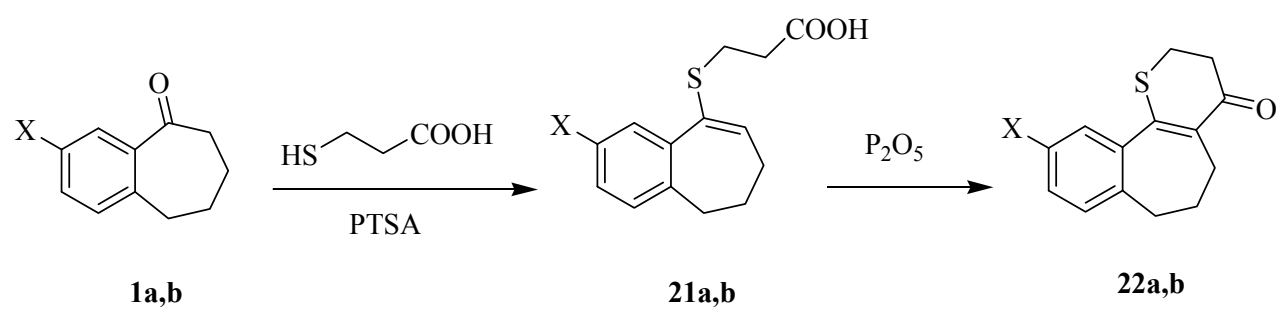

a, $\mathrm{X}=\mathrm{H}, \mathbf{b}, \mathrm{X}=\mathrm{NO}_{2}$

Scheme 6. Synthetic routes for compounds $21 \mathbf{a}, \mathbf{b}$ and $22 \mathbf{a}, \mathbf{b}$.

Treatment of the thiopyran-4(5H)-one derivatives $\mathbf{2 2 a}$, $\mathbf{b}$ in step 1 with 3-mercaptopropanoic acid in refluxing benzene, in the presence of 4-toluenesulfonic acid (PTSA), afford the non-isolated intermediates 23a,b that undergo intramolecular cyclization under reflux temperature using phosphorus pentoxide to afford the novel tetracyclic ring systems $\mathbf{2 4 a} \mathbf{a} \mathbf{b}$ (Scheme 7). The structures of compounds $\mathbf{2 4 a , b}$ were established on the basis of their elemental analysis and spectral data. The IR spectrum of compound 24a showed the presence of the carbonyl band at $1692 \mathrm{~cm}^{-1}$. The ${ }^{1} \mathrm{H}-\mathrm{NMR}$ spectrum of 24 revealed multplites at $2.25-2.50$ and $3.25-3.38 \mathrm{ppm}$ corresponding to $5 \mathrm{CH}_{2}$ groups, in addition to the signal at $3.73 \mathrm{ppm}$ corresponding to $\mathrm{CH}_{2}$ of the thiopyran protons.

The later products were oxidized using hydrogen peroxide under reflux condition to afford the oxidized form of the novel tetracyclic derivatives $25 \mathbf{a}, \mathbf{b}$ (Scheme 7 ).

Due to the oxidation of compounds $24 \mathbf{a}, \mathbf{b}$ to compounds $25 \mathbf{a}, \mathbf{b}$, the carbonyl band in the IR spectrum of compound 25a for example shifted to $1695 \mathrm{~cm}^{-1}$. The ${ }^{1} \mathrm{H}-\mathrm{NMR}$ spectrum of compound 25a revealed multplites near 1.76, 2.15, 2.63 and $3.27 \mathrm{ppm}$ corresponding to $5 \mathrm{CH}_{2}$ groups, in addition to signal at $2.63 \mathrm{ppm}$ corresponding to $\mathrm{CH}_{2}$ of the dioxothiopyran protons. 


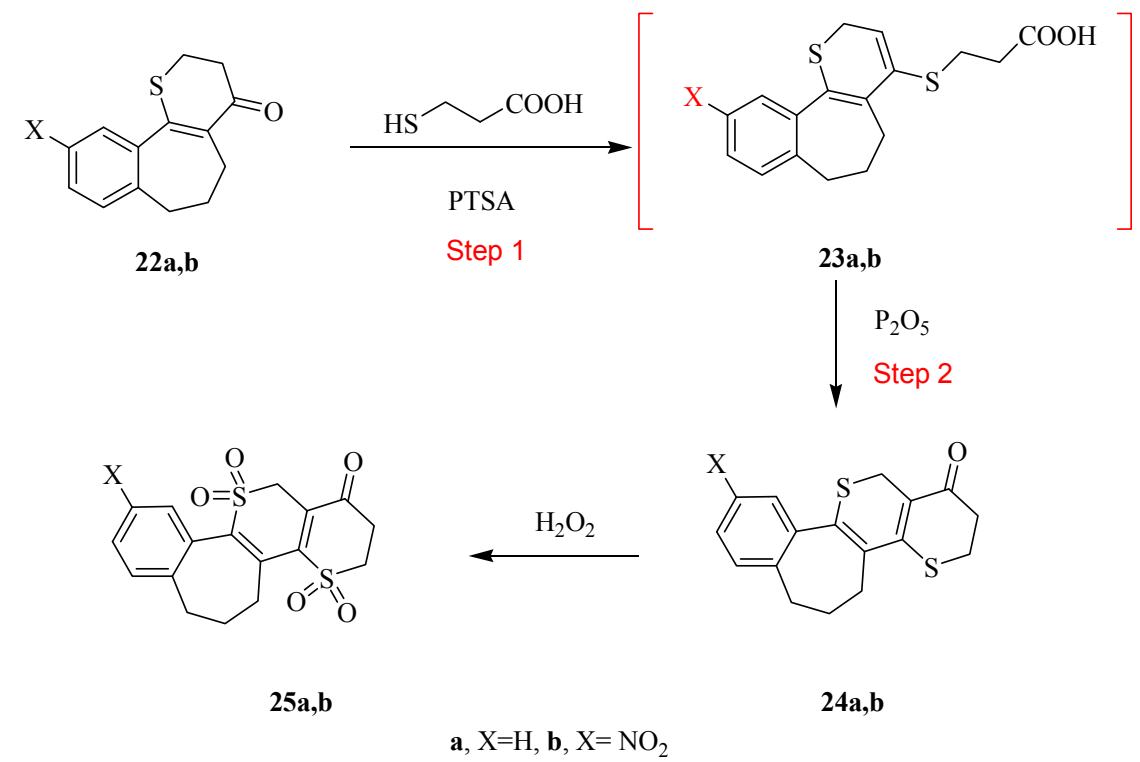

Scheme 7. Synthetic routes for compounds 24 and 25.

\subsection{Antimicrobial Screening}

The in vitro antimicrobial activity of the synthesized compounds was screened against three gram-positive bacteria (Bacillus subtilits, Staphylococcus aureus and Enterococcus faecalis) and three gram-negative bacteria (Escherichia coli, Pseudomonas aeruginosa and Proteus sp.), yeast (Candida albicans) and filamentous fungi (Aspergillus niger and A. flavus). The tested products have shown a strong to moderate effect against most of the tested pathogens.

Most of the compounds showed a moderate inhibitory effect against Gram-positive bacteria (Bacillus subtilits, Staphylococcus aureus and Enterococcus faecalis) except compounds 25b and 22a, which showed strong inhibition effect in comparison with the standard antibiotics used (Table 1). On the other hand, five compounds $25 \mathbf{b}, \mathbf{9 c}, \mathbf{1 9 b}, \mathbf{2 1} \mathbf{b}$ and $\mathbf{5 a}$ showed a strong inhibitory effect (15-25 mm) against Escherichia coli, as an example of Gram-negative bacteria. While the others showed a weak to a moderate inhibition effect against Pseudomonas aeruginosa, Proteus sp. The antifungal activities are presented in Table 1. In case of unicellular fungi most of the compounds showed a strong antifungal effect against Candida albicans. These compounds are 22a, 25b, 21a, 9c and 19b while the other compounds were characterized by moderate antifungal effect. In the case of filamentous fungi, compounds 22a, 25b, 4b, 5a, 5b, 9c, 19d, 22b and 24a have a higher antifungal effect against Aspergillus niger and a moderate activity against $A$. flavus in comparison with the antifungal standard antibiotic (Neomycin) used in this study. Finally, the demonstration of the activity of compound $\mathbf{2 5 b}$ against gram-positive bacteria, gram-negative bacteria, and fungi is an indication that this compound can be used in the treatment of the tested pathogens due to its broad spectrum effect.

The structure-activity relationships (SAR) of these synthesized compounds (Tetracyclic derivatives) may be due to their ability for inhibiting the cell growth by inhibiting the protein synthesis $[17,18]$.

The minimum inhibitory concentration (MIC) of the synthesized compounds is presented in the Table 2. The MIC varied from 50 to $500 \mu \mathrm{g} / \mathrm{mL}$ based on the tested compounds. The MIC of the compound $\mathbf{2 5 b}$ was 50,50, 75 and $100 \mu \mathrm{g} / \mathrm{mL}$ against tested pathogens E. coli, C. albicans, B. subtilis and A. niger. On the other hand, the MIC of the compound 22a was $100 \mu \mathrm{g} / \mathrm{mL}$ against Bacillius sutbtilis, while the MIC of the compound $9 \mathrm{c}$ was $200 \mu \mathrm{g} / \mathrm{mL}$ against Bacillius sutbtilis. Finally, we can interpret that some of samples have strongest antifungal and antibacterial activities. The demonstration of the activity against gram-positive bacteria, gram-negative bacteria, and fungi is 
an indication that the compounds have a broad spectrum effect. A few of the test compounds possessed a broad spectrum of activity having MIC values ranging from 50 to $200 \mu \mathrm{g} / \mathrm{mL}$.

Table 1. Antimicrobial activity of compounds at $10 \mathrm{mg} / \mathrm{mL}$.

\begin{tabular}{|c|c|c|c|c|c|c|c|c|c|}
\hline \multirow{3}{*}{ Comp. No. } & \multicolumn{6}{|c|}{ Bacteria } & \multicolumn{3}{|c|}{ Fungi } \\
\hline & \multicolumn{3}{|c|}{ G + ve } & \multicolumn{3}{|c|}{ G - ve } & \multirow{2}{*}{$\begin{array}{l}\text { unicellular } \\
\text { C. albicans } \\
\end{array}$} & \multicolumn{2}{|c|}{ filamentous } \\
\hline & B. subtilits & S. aureus & Ent. faecalis & E. coli & P. aeruginosa & Proteus sp. & & A. niger & A. flavus \\
\hline $4 a$ & 17 & 17 & 14 & 17 & 14 & 15 & 15 & 12 & 11 \\
\hline $4 b$ & 15 & 15 & 12 & 15 & 12 & 13 & 00 & 20 & 18 \\
\hline $5 a$ & 00 & 18 & 15 & 18 & 15 & 14 & 15 & 20 & 19 \\
\hline $5 b$ & 00 & 12 & 11 & 12 & 11 & 12 & 15 & 20 & 15 \\
\hline $9 a$ & 12 & 00 & 00 & 00 & 00 & 00 & 00 & 00 & 00 \\
\hline $9 b$ & 12 & 00 & 00 & 00 & 00 & 00 & 00 & 00 & 00 \\
\hline $9 \mathrm{c}$ & 22 & 20 & 17 & 20 & 18 & 17 & 17 & 20 & 16 \\
\hline $16 \mathbf{a}$ & 20 & 16 & 14 & 16 & 14 & 15 & 00 & 00 & 00 \\
\hline $16 b$ & 12 & 00 & 00 & 00 & 00 & 00 & 00 & 00 & 00 \\
\hline $16 \mathrm{c}$ & 15 & 15 & 13 & 15 & 12 & 13 & 00 & 00 & 00 \\
\hline $16 \mathrm{~d}$ & 14 & 13 & 12 & 13 & 12 & 11 & 00 & 00 & 00 \\
\hline $19 a$ & 12 & 00 & 00 & 00 & 00 & 00 & 00 & 00 & 00 \\
\hline $19 b$ & 22 & 20 & 17 & 20 & 17 & 18 & 17 & 00 & 00 \\
\hline $19 \mathrm{c}$ & 12 & 00 & 00 & 00 & 00 & 00 & 00 & 00 & 00 \\
\hline 19d & 20 & 17 & 14 & 17 & 14 & 15 & 00 & 20 & 17 \\
\hline $21 a$ & 17 & 15 & 13 & 15 & 12 & 13 & 20 & 00 & 00 \\
\hline $21 b$ & 14 & 20 & 18 & 20 & 15 & 17 & 00 & 00 & 00 \\
\hline $22 a$ & 25 & 00 & 00 & 00 & 00 & 00 & 30 & 40 & 20 \\
\hline $22 b$ & 15 & 00 & 00 & 00 & 00 & 00 & 15 & 18 & 16 \\
\hline $24 a$ & 15 & 00 & 00 & 00 & 00 & 00 & 15 & 18 & 15 \\
\hline $24 b$ & 12 & 00 & 00 & 00 & 00 & 00 & 15 & 00 & 00 \\
\hline $25 a$ & 17 & 00 & 00 & 00 & 00 & 00 & 00 & 00 & 00 \\
\hline $25 b$ & 27 & 25 & 19 & 25 & 19 & 20 & 25 & 29 & 20 \\
\hline $\mathrm{S}^{*}=10 \mu \mathrm{g}$ & 14 & 00 & 00 & 00 & 00 & 00 & 12 & 00 & 00 \\
\hline $\mathrm{TE}^{*}=30 \mu \mathrm{g}$ & 10 & 00 & 00 & 00 & 00 & 00 & 23 & 00 & 00 \\
\hline $\mathrm{N}^{*}=30 \mu \mathrm{g}$ & 00 & 00 & 00 & 00 & 00 & 00 & 00 & 16 & 14 \\
\hline $\mathrm{T}^{*}=30 \mu \mathrm{g}$ & 30 & 00 & 00 & 00 & 00 & 00 & 00 & 00 & 00 \\
\hline
\end{tabular}

* S = Streptomycin; TE = Tetracycline; $\mathrm{N}=$ Neomycin and $\mathrm{T}=$ Oxytetracyciline.

Table 2. Minimum inhibitory concentration (MIC) of different compounds against of tested pathogens.

\begin{tabular}{cccccccccc}
\hline \multirow{2}{*}{ Comp. No. } & \multicolumn{4}{c}{ Inhibition Zone Diameters $(\mathrm{mm})$} & \multicolumn{4}{c}{ MIC $(\mu \mathrm{g} / \mathrm{mL})$} \\
\cline { 2 - 9 } & B. sutbtilis & E. coli & C. albicans & A. niger & B. sutbtilis & E. coli & C. albicans & A. niger \\
\hline 25b & 11 & 11 & 11 & 11 & 75 & 50 & 50 & 100 \\
22a & 11 & - & - & - & 100 & - & - & - \\
9c & 11 & - & - & - & 200 & - & - & - \\
\hline
\end{tabular}

\section{Experimental Section}

\subsection{Chemistry}

All melting points were measured on a Gallenkamp melting point apparatus (Weiss Gallenkamp, London, UK). The infrared spectra were recorded in potassium bromide disks on a PyeUnicam SP 3300 and Shimadzu FT IR 8101 PC infrared spectrophotometers (PyeUnicam Ltd. Cambridge, UK and Shimadzu, Tokyo, Japan, respectively). The NMR spectra were recorded on a Varian Mercury VX-300 NMR spectrometer (Varian, Palo Alto, CA, USA). ${ }^{1} \mathrm{H}$ spectra were run at $300 \mathrm{MHz}$ and ${ }^{13} \mathrm{C}$ spectra were run at $75.46 \mathrm{MHz}$ in deuterated chloroform $\left(\mathrm{CDCl}_{3}\right)$ or dimethyl sulfoxide $\left(\right.$ DMSO- $\left.d_{6}\right)$. (Sigma-Aldrich, St. Louis, MO, USA). Chemical shifts are given in parts per million and were related to that of the solvent. Mass spectra were recorded on a Shimadzu GCMS-QP 1000 EX mass spectrometer (Shimadzu, Tokyo, Japan) at $70 \mathrm{eV}$. Elemental analyses were carried out at the Micro-analytical Centre of Cairo University, Giza, Egypt and recorded on Elementar-Vario EL (ELTRA GmbH, Haan, Germany) automatic analyzer. Compounds $\mathbf{1 b}, \mathbf{1 4 a}-\mathbf{c}$ and 18a-c were prepared by following the reported procedures in the literature [19-22]. The in vitro antimicrobial screening was performed by Chemistry of Natural and Microbial Products Dept., National Research Centre, Cairo-12622, Cairo, Egypt. 


\subsubsection{Preparation of the Thioamide Derivatives $4 \mathbf{a}, \mathbf{b}$}

A solution of finely ground $\mathrm{KOH}(0.12 \mathrm{~g}, 2 \mathrm{mmol})$ and benzosuberone derivatives $\mathbf{1 a}, \mathbf{b}(2 \mathrm{mmol})$ in DMF $(10 \mathrm{~mL})$, was stirred for $2 \mathrm{~h}$. Phenyl isothiocyanate $(0.27 \mathrm{~g}, 10.0 \mathrm{mmol})$ was then added drop-wise and the mixture was stirred for 10-12 h. The mixture was poured onto cold water acidified with $1 \mathrm{~N} \mathrm{HCl}$. the solid product obtained was filtered off, washed with water, dried, and finally recrystallized with the prober solvent to afford the thioamidederivatives $\mathbf{4 a}, \mathbf{b}$.

6,7,8,9-Tetrahydro-6-(mercapto(phenylamino)methylene)benzo[7]annulen-5-one 4a. Yield: (0.24 g, 81\%); mp: $185-187^{\circ} \mathrm{C}$; as a pale yellow crystals (MeOH). IR $\left(\mathrm{KBr}, \mathrm{cm}^{-1}\right)$ v $3430(\mathrm{NH}), 1637(\mathrm{C}=\mathrm{O}) .{ }^{1} \mathrm{H}-\mathrm{NMR}$ (DMSO- $\left.d_{6}\right): \delta 1.90\left(\mathrm{~m}, 2 \mathrm{H}, \mathrm{CH}_{2}\right), 2.41-3.20\left(\mathrm{~m}, 4 \mathrm{H}, 2 \mathrm{CH}_{2}\right), 6.99-7.90(\mathrm{~m}, 9 \mathrm{H}, \mathrm{Ar}-\mathrm{H}), 8.50(\mathrm{br} \mathrm{s}, 1 \mathrm{H}, \mathrm{NH}$, $\mathrm{D}_{2} \mathrm{O}$ exchangeable). MS m/z (\%): $296[\mathrm{M}+1]^{+}$(5), $295[\mathrm{M}]^{+}$(25), 219 (10), 205 (40), 160 (30), 92 (100), 77 (50). Anal. Calcd. for $\mathrm{C}_{18} \mathrm{H}_{17} \mathrm{NOS}$ (295.40): C, 73.19; H, 5.80; N, 4.74; S, 10.85. Found: C, 73.44; $\mathrm{H}, 5.89 ; \mathrm{N}, 4.62 ; \mathrm{S}, 10.79$.

6,7,8,9-Tetrahydro-6-(mercapto(phenylamino)methylene)-3-nitrobenzo[7]annulen-5-one $\mathbf{4 b}$. Yield: (0.27 g, 79\%); mp: 215-217 ${ }^{\circ} \mathrm{C}$; yellow crystals $(\mathrm{EtOH})$. IR $\left(\mathrm{KBr}, \mathrm{cm}^{-1}\right)$ : $v 3433(\mathrm{NH}), 1663(\mathrm{C}=\mathrm{O})$. ${ }^{1} \mathrm{H}-\mathrm{NMR}\left(\mathrm{DMSO}-d_{6}\right): \delta 1.94-3.30\left(\mathrm{~m}, 6 \mathrm{H}, 3 \mathrm{CH}_{2}\right), 7.01-8.27(\mathrm{~m}, 8 \mathrm{H}, \mathrm{Ar}-\mathrm{H}), 9.20\left(\mathrm{br} \mathrm{s}, 1 \mathrm{H}, \mathrm{NH}, \mathrm{D}_{2} \mathrm{O}\right.$ exchangeable). ${ }^{13} \mathrm{H}-\mathrm{NMR}$ (DMSO- $\left.d_{6}\right): \delta 25.41,25.60,39.90,115.68,119.98,120.39,124.39,129.51$, $130.88,138.88,139.05,142.92,147.15,155.41,189.93 . \mathrm{MS} m / z(\%): 341[\mathrm{M}+1]^{+}(3), 340[\mathrm{M}]^{+}(15), 338$ (100), 262 (35), 205 (60). Anal. Calcd. for $\mathrm{C}_{18} \mathrm{H}_{16} \mathrm{~N}_{2} \mathrm{O}_{3} \mathrm{~S}$ (340.40): C, 63.51; H, 4.74; N, 8.23; S, 9.42. Found: C, 63.44; H, 4.69; N, 7.97; S, 9.48 .

\subsubsection{General Procedure for Preparation of the S-Methylated Thioamide Derivatives $\mathbf{5 a}, \mathbf{b}$}

To a stirred solution of the thioamide derivatives $4 \mathbf{a}, \mathbf{b}(1 \mathrm{mmol})$ and potassium carbonate $(0.14 \mathrm{~g}$, $1 \mathrm{mmol})$ in DMF $(10 \mathrm{~mL})$, iodomethane $(0.28 \mathrm{~g}, 2 \mathrm{mmol})$ was added and stirring was continued for another $12 \mathrm{~h}$. The mixture was poured onto crushed ice and the solid product obtained was filtered off, washed with water, dried, and finally recrystallized from the prober solvent to afford colorless crystals of compounds $\mathbf{5 a}, \mathbf{b}$.

6,7,8,9-Tetrahydro-6-(methylthio(phenylamino)methylene)benzo[7]annulen-5-one 5a. Yield: (0.26 g, 84\%); mp: $195-197^{\circ} \mathrm{C}$; buff powder (MeOH/dioxan). IR $\left(\mathrm{KBr}, \mathrm{cm}^{-1}\right)$ : $v 3400(\mathrm{NH}), 1674(\mathrm{C}=\mathrm{O}) .{ }^{1} \mathrm{H}-\mathrm{NMR}$ (DMSO- $\left.d_{6}\right): \delta 1.77-2.51\left(\mathrm{~m}, 6 \mathrm{H}, 3 \mathrm{CH}_{2}\right), 3.08\left(\mathrm{~s}, 3 \mathrm{H}, \mathrm{CH}_{3}\right), 6.86-7.79(\mathrm{~m}, 9 \mathrm{H}, \mathrm{Ar}-\mathrm{H}), 8.31(\mathrm{br} \mathrm{s}, 1 \mathrm{H}, \mathrm{NH}$, $\mathrm{D}_{2} \mathrm{O}$ exchangeable). MS m/z (\%): $310[\mathrm{M}+1]^{+}(8), 309\left[\mathrm{M}^{+}(45), 261(30), 217\right.$ (20), 115 (70), 91 (50), 77 (100). Anal. Calcd. for $\mathrm{C}_{19} \mathrm{H}_{19} \mathrm{NOS}$ (309.43): C, 73.75; H, 6.19; N, 4.53; S, 10.36. Found: C, 73.52; $\mathrm{H}, 6.10 ; \mathrm{N}, 4.62 ; \mathrm{S}, 10.44$.

6,7,8,9-Tetrahydro-6-(methylthio(phenylamino)methylene)-3-nitrobenzo[7]annulen-5-one $5 \mathbf{b}$. Yield: (0.31 g, 84\%); mp: $225-22{ }^{\circ} \mathrm{C}$; pale yellow crystals (EtOH/DMF). IR $\left(\mathrm{KBr}, \mathrm{cm}^{-1}\right): v 3430(\mathrm{NH}), 1664(\mathrm{C}=\mathrm{O})$. ${ }^{1} \mathrm{H}-\mathrm{NMR}$ (DMSO- $\left.d_{6}\right): \delta 1.77\left(\mathrm{~m}, 2 \mathrm{H}, \mathrm{CH}_{2}\right), 2.30-2.51\left(\mathrm{~m}, 4 \mathrm{H}, 2 \mathrm{CH}_{2}\right), 3.30\left(\mathrm{~s}, 3 \mathrm{H}, \mathrm{CH}_{3}\right), 7.18-8.57(\mathrm{~m}$, $8 \mathrm{H}, \mathrm{Ar}-\mathrm{H}), 9.01$ (br s, 1H, NH, $\mathrm{D}_{2} \mathrm{O}$ exchangeable). MS m/z (\%): $355[\mathrm{M}+1]^{+}$(5), $354[\mathrm{M}]^{+}(25), 205$ (35), 159 (40), 93 (100), 77(70). Anal. Calcd. for $\mathrm{C}_{19} \mathrm{H}_{18} \mathrm{~N}_{2} \mathrm{O}_{3} \mathrm{~S}$ (354.42): C, 64.39; H, 5.12; N, 7.90; S, 9.05. Found: C, 64.26; H, 5.03; N, 7.78; S, 9.14.

3.1.3. Reaction of Thioamide Derivatives 4 with $\alpha$-Halo Carbonyl Compounds: General Procedure for the Preparation of $\mathbf{9 a - c}$

Method A: To a solution of the thioamide derivatives $4 \mathbf{a}$ and $4 \mathbf{b}(1 \mathrm{mmol})$ and $1 \mathrm{mmol}$ of chloroacetone 6 or phenacyl chloride 7 in EtOH $(10 \mathrm{~mL}), 0.2 \mathrm{~mL}$ of triethylamine were added. The reaction mixture was refluxed for $10-15 \mathrm{~h}$ and then allowed to cool. The solid product obtained was filtered off, washed with $\mathrm{EtOH}$, dried, and finally recrystallized from the prober solvent to afford the corresponding thiophenes $\mathbf{9 a}-\mathbf{c}$, respectively. 
By the same method, $4 \mathbf{a}(1 \mathrm{mmol})$ was reacted with 3-chloroacetyl acetone (1 mmol) to afford 9a, which is identical in all respects ( $\mathrm{mp}$, TLC and spectra) in comparison with an authentic sample that obtained from the reaction of $\mathbf{4 a}$ and chloroacetone.

Method B: To a mixture of the thioamide derivatives $4 \mathbf{a}, \mathbf{b}(1 \mathrm{mmol})$ and chloroacetone $\mathbf{6}$ or phenacyl chloride 7 ( $1 \mathrm{mmol})$ in DMF $(5 \mathrm{~mL}), 0.19 \mathrm{~g}$ potassium carbonate was added. The reaction mixture was stirred at ambient temperature for $10 \mathrm{~h}$, and then poured onto ice cold water acidified with $1 \mathrm{~N} \mathrm{HCl}$. The solid product obtained was filtered off, washed with water, dried and finally recrystallized from the prober solvent to afford products identical in all respect with compounds 9a-d.

(2-Acetyl-5-phenylimimno)thiophen[c,f]benzo[7]anulene 9a. Yield: (0.29 g, 87\%); mp: 187-190 ${ }^{\circ} \mathrm{C}$; buff powder $(\mathrm{MeOH})$. IR $\left(\mathrm{KBr}, \mathrm{cm}^{-1}\right): v 3430(\mathrm{NH}), 1691(\mathrm{C}=\mathrm{O}) .{ }^{1} \mathrm{H}-\mathrm{NMR}\left(\mathrm{DMSO}-d_{6}\right): \delta 1.72(\mathrm{~m}, 2 \mathrm{H}$, $\left.\mathrm{CH}_{2}\right), 2.15-2.64\left(\mathrm{~m}, 4 \mathrm{H}, 2 \mathrm{CH}_{2}\right), 2.80\left(\mathrm{~s}, 3 \mathrm{H}, \mathrm{CH}_{3}\right), 6.97-7.59(\mathrm{~m}, 9 \mathrm{H}, \mathrm{Ar}-\mathrm{H}), 8.60\left(\mathrm{~s}, 1 \mathrm{H}, \mathrm{NH}, \mathrm{D}_{2} \mathrm{O}\right.$ exchangeable). MS m/z (\%): $334[\mathrm{M}+1]^{+}(7), 333[\mathrm{M}]^{+}$(35), 308 (50), 293 (15), $194(20), 118$ (100), 92 (15), 77 (40). Anal. Calcd. for $\mathrm{C}_{21} \mathrm{H}_{19} \mathrm{NOS}$ (333.45): C, 75.64; H, 5.74; N, 4.20; S, 9.62. Found: C, 75.32; $\mathrm{H}, 5.61 ; \mathrm{N}, 4.05 ; \mathrm{S}, 9.74$.

(2-Acetyl-5-phenylimino)thiophen[c,f]-3-nitrobenzo[7]anulene 9b. Yield: $(0.30 \mathrm{~g}, 80 \%)$; mp: $200-202{ }^{\circ} \mathrm{C}$; yellow crystals $(\mathrm{EtOH})$. IR $\left(\mathrm{KBr}, \mathrm{cm}^{-1}\right): v 3428(\mathrm{NH}), 1654(\mathrm{C}=\mathrm{O}) .{ }^{1} \mathrm{H}-\mathrm{NMR}\left(\mathrm{DMSO}-d_{6}\right): \delta 1.72(\mathrm{~m}$, $\left.2 \mathrm{H}, \mathrm{CH}_{2}\right), 2.35-2.591\left(\mathrm{~m}, 4 \mathrm{H}, 2 \mathrm{CH}_{2}\right), 3.30\left(\mathrm{~s}, 3 \mathrm{H}, \mathrm{CH}_{3}\right), 6.68-8.72(\mathrm{~m}, 8 \mathrm{H}, \mathrm{Ar}-\mathrm{H}), 9.53\left(\mathrm{~s}, 1 \mathrm{H}, \mathrm{NH}, \mathrm{D}_{2} \mathrm{O}\right.$ exchangeable). ${ }^{13} \mathrm{H}-\mathrm{NMR}$ (DMSO- $\left.d_{6}\right): \delta 21.35,28.23,34.12,39.45,116.30,119.35,122.21,123.10,125.50$, 129.60, 135.90, 136.10, 138.50, 141.33, 143.31, 145.21, 150.13, 187.21. MS m/z (\%): $379[\mathrm{M}+1]^{+}(4), 378$ $[\mathrm{M}]^{+}$(25), 343 (10), 258 (40), 212 (100), 200 (35), 142 (70), 91 (65), 77 (60). Anal. Calcd. for $\mathrm{C}_{21} \mathrm{H}_{18} \mathrm{~N}_{2} \mathrm{O}_{3} \mathrm{~S}$ (378.44): C, 66.65; H, 4.79; N, 7.40; S, 8.47. Found: C, 66.51; H, 4.73; N, 7.47; S, 8.55.

(2-Benzoyl-5-phenylimino)thiophen[c,f]benzo[7]anulen (9c). Yield: (0.31 g, 81\%); mp: 195-198 ${ }^{\circ} \mathrm{C}$; yellow powder $(\mathrm{EtOH})$. IR $\left(\mathrm{KBr}, \mathrm{cm}^{-1}\right): v 3425(\mathrm{NH}), 1681(\mathrm{C}=\mathrm{O}) .{ }^{1} \mathrm{H}-\mathrm{NMR}\left(\mathrm{DMSO}-d_{6}\right): \delta 1.82-2.84(\mathrm{~m}, 6 \mathrm{H}$, $\left.3 \mathrm{CH}_{2}\right), 6.97-7.59(\mathrm{~m}, 14 \mathrm{H}, \mathrm{Ar}-\mathrm{H}), 8.60\left(\mathrm{~s}, 1 \mathrm{H}, \mathrm{NH}, \mathrm{D}_{2} \mathrm{O}\right.$ exchangeable). MS m/z (\%): $396[\mathrm{M}+1]^{+}(10)$, $395 \mathrm{M}^{+}$(45), 303 (25), 293 (15), 199 (30), 115 (100), 92 (77), 77 (40). Anal. Calcd. for $\mathrm{C}_{26} \mathrm{H}_{21} \mathrm{NOS}$ (395.52): C, 78.95; H, 5.35; N, 3.54; S, 8.11. Found: C, 78.84; H, 5.28; N, 3.62; S, 8.15.

3.1.4. Reactions of Thioamide Derivatives $\mathbf{4 a} \mathbf{a}, \mathbf{b}$ with $C$-Acetyl-N-arylhydrazonoyl Chlorides $14 \mathbf{a}, \mathbf{b}$ and $C$-Ethoxycarbonyl- $N$-arylhydrazonoyl chlorides $\mathbf{1 8 a}, \mathbf{b}$

The reactions of the thioamide derivatives $4 \mathbf{a}$ and $\mathbf{4 b}$ with hydrazonoyl chlorides $\mathbf{1 4 a , b}$ and/or $\mathbf{1 8} \mathbf{a}, \mathbf{b}$, were carried out as described above for the synthesis of thiophene derivatives (method A), to afford the corresponding 1,3,4-thiadiazol derivatives $\mathbf{1 6 a - d}$ and $\mathbf{1 9 a}-\mathbf{d}$, respectively.

6-(5-Acetyl-3-p-tolyl-1,3,4-thiadiazol-2(3H)-ylidene)-6,7,8,9-tetrahydrobenzo[7]-annulen-5-one 16a. Yield: (0.3 g, 79\%); mp: $225-227^{\circ} \mathrm{C}$; yellow powder (MeOH/dioxan). IR (KBr, cm $\left.{ }^{-1}\right)$ : v 1668, $1653(\mathrm{C}=\mathrm{O})$. ${ }^{1} \mathrm{H}-\mathrm{NMR}\left(\mathrm{DMSO}-d_{6}\right): \delta 1.57\left(\mathrm{~m}, 2 \mathrm{H}, \mathrm{CH}_{2}\right), 2.40-2.46\left(\mathrm{~m}, 4 \mathrm{H}, 2 \mathrm{CH}_{2}\right), 3.10\left(\mathrm{~s}, 3 \mathrm{H}, \mathrm{CH}_{3}\right), 3.43(\mathrm{~s}, 3 \mathrm{H}$, $\left.\mathrm{CH}_{3}\right), 7.10-7.50(\mathrm{~m}, 8 \mathrm{H}, \mathrm{Ar}-\mathrm{H}) . \mathrm{MS} m / z(\%): 377[\mathrm{M}+1]^{+}$(9), $376[\mathrm{M}]^{+}$(75), 187 (45), 160 (20), 91 (80), 86 (100). Anal. Calcd. for $\mathrm{C}_{22} \mathrm{H}_{20} \mathrm{~N}_{2} \mathrm{O}_{2} \mathrm{~S}$ (376.47): C, 70.19; H, 5.35; N, 7.44; S, 8.52 . Found: C, 69.98; H, 5.19; N, 7.66; S, 8.47.

6-(5-Acetyl-3-p-tolyl-1,3,4-thiadiazol-2(3H)-ylidene)-6,7,8,9-tetrahydro-3-nitrobenzo[7]-annulen-5-one 16b. Yield: (0.38 g, 90\%); mp: 260-262 ${ }^{\circ} \mathrm{C}$; brown crystals (EtOH/dioxan). IR (KBr, cm $\left.{ }^{-1}\right): v 1690,1645$ $(\mathrm{C}=\mathrm{O}) .{ }^{1} \mathrm{H}-\mathrm{NMR}\left(\mathrm{DMSO}-d_{6}\right): \delta 1.70\left(\mathrm{~m}, 2 \mathrm{H}, \mathrm{CH}_{2}\right), 2.40-2.46\left(\mathrm{~m}, 4 \mathrm{H}, 2 \mathrm{CH}_{2}\right), 3.10\left(\mathrm{~s}, 3 \mathrm{H}, \mathrm{CH}_{3}\right), 3.43(\mathrm{~s}$, $\left.3 \mathrm{H}, \mathrm{CH}_{3}\right), 7.30-7.90$ (m, 7H, Ar-H). MS m/z (\%): $423[\mathrm{M}+2]^{+}(11), 421[\mathrm{M}]^{+}$(55), 287 (15), 203 (30), 159 (20), 91 (35). Anal. Calcd. For $\mathrm{C}_{22} \mathrm{H}_{19} \mathrm{~N}_{3} \mathrm{O}_{4} \mathrm{~S}$ (421.47): C, 62.69; H, 4.54; N, 9.97; S, 7.61. Found: C, 62.35; H, 4.39; N, 10.14; S, 7.41.

6-(5-Acetyl-3-(4-fluorophenyl)-1,3,4-thiadiazol-2(3H)-ylidene)-6,7,8,9-tetrahydrobenzo[7]-annulen-5-one 16c. Yield: (0.32 g, 85\%); mp: $240-242{ }^{\circ} \mathrm{C}$; gray powder (dioxan). IR $\left(\mathrm{KBr}, \mathrm{cm}^{-1}\right)$ : v 1671, $1653(\mathrm{C}=\mathrm{O})$. ${ }^{1} \mathrm{H}-\mathrm{NMR}\left(\mathrm{DMSO}-d_{6}\right): \delta 1.53\left(\mathrm{~m}, 2 \mathrm{H}, \mathrm{CH}_{2}\right), 2.38-2.46\left(\mathrm{~m}, 4 \mathrm{H}, 2 \mathrm{CH}_{2}\right), 3.43\left(\mathrm{~s}, 3 \mathrm{H}, \mathrm{CH}_{3}\right), 6.76-7.40(\mathrm{~m}$, $8 \mathrm{H}, \mathrm{Ar}-\mathrm{H}) .{ }^{13} \mathrm{H}-\mathrm{NMR}\left(\mathrm{DMSO}-d_{6}\right): \delta 23.13,23.80,25.41,38.90,116.44,117.60,119.90,126.23,128.75$, 
$130.67,134.28,136.13,140.35,145.24,151.20,154.31,187.23,195.25 . \mathrm{MS} m / z(\%): 381[\mathrm{M}+1]^{+}(9), 380$ $[\mathrm{M}]^{+}$(45), 187 (25), 160 (27), 91 (85), 86 (100). Anal. Calcd. For $\mathrm{C}_{21} \mathrm{H}_{17} \mathrm{~N}_{2} \mathrm{O}_{2} \mathrm{~S}$ (380.44): C, 66.30; H, 4.50; N, 7.36; S, 8.43. Found: C, 66.11; H, 4.37; N, 7.55; S, 8.64.

6-(5-Acetyl-3-(4-fluorophenyl)-1,3,4-thiadiazol-2(3H)-ylidene)-6,7,8,9-tetrahydro-3-nitrobenzo-[7]annulen-5one 16d. Yield: $(0.35 \mathrm{~g}, 87 \%)$; mp: $275-277^{\circ} \mathrm{C}$; green crystals $(\mathrm{EtOH} / \mathrm{DMF}) . \mathrm{IR}\left(\mathrm{KBr}, \mathrm{cm}^{-1}\right): v 1680$, $1655(\mathrm{C}=\mathrm{O}) .{ }^{1} \mathrm{H}-\mathrm{NMR}\left(\mathrm{DMSO}-d_{6}\right): \delta 1.57\left(\mathrm{~m}, 2 \mathrm{H}, \mathrm{CH}_{2}\right), 2.03-2.56\left(\mathrm{~m}, 4 \mathrm{H}, 2 \mathrm{CH}_{2}\right), 3.43\left(\mathrm{~s}, 3 \mathrm{H}, \mathrm{CH}_{3}\right)$, 6.76-8.40 (m, 7H, Ar-H). MS m/z (\%): 425 [M] $]^{+}$(30) 245 (45), 171 (20), 95 (100), 77 (60). Anal. calcd. for $\mathrm{C}_{21} \mathrm{H}_{16} \mathrm{~N}_{3} \mathrm{O}_{4} \mathrm{~S}$ (425.43): C, 59.29; H, 3.79; N, 9.88; S, 7.54. Found: C, 59.09; H, 3.67; N, 10.17; S, 7.73.

Ethyl 4,5-Dihydro-5-(5,6-dihydro-9-oxo-5H-benzo[7]annulen-8(7H)-ylidene)-4-phenyl-1,3,4-thiadiazole-2carboxylate 19a. Yield: $(0.31 \mathrm{~g}, 79 \%)$; mp: $218-220{ }^{\circ} \mathrm{C}$; brown crystals $(\mathrm{EtOH} / \mathrm{DMF}) . \mathrm{IR}\left(\mathrm{KBr}, \mathrm{cm}^{-1}\right)$ : $v$ 1718, $1675(\mathrm{C}=\mathrm{O}) .{ }^{1} \mathrm{H}-\mathrm{NMR}\left(\mathrm{DMSO}-d_{6}\right): \delta 1.71\left(\mathrm{~m}, 2 \mathrm{H}, \mathrm{CH}_{2}\right), 2.36-2.80\left(\mathrm{~m}, 6 \mathrm{H}, 3 \mathrm{CH}_{2}\right), 4.2(\mathrm{q}$, $\left.J=7.1 \mathrm{~Hz}, 2 \mathrm{H}, \mathrm{CH}_{3}\right), 6.76-7.20(\mathrm{~m}, 9 \mathrm{H}, \mathrm{Ar}-\mathrm{H}),{ }^{13} \mathrm{H}-\mathrm{NMR}\left(\mathrm{DMSO}_{6}\right): \delta 13.80,21.35,23.85,35.55$, $60.25,116.30,118.82,126.62,128.70,129.60,130.60,133.00,134.72,140.40,141.80,154.50,161.12,178.35$. MS m/z (\%): $393[\mathrm{M}+1]^{+}(6), 392[\mathrm{M}]^{+}(25), 346(20), 194(15), 242(45), 150(30), 92(100), 77(80), 65$ (60). Anal. Calcd. for $\mathrm{C}_{22} \mathrm{H}_{20} \mathrm{~N}_{2} \mathrm{O}_{3} \mathrm{~S}$ (392.47): $\mathrm{C}, 67.33 ; \mathrm{H}, 5.14 ; \mathrm{N}, 7.14 ; \mathrm{S}, 8.17$. Found: $\mathrm{C}, 67.12 ; \mathrm{H}$, $4.98 ; \mathrm{N}, 7.35 ; \mathrm{S}, 8.34$.

Ethyl 4,5-Dihydro-5-(6,7-dihydro-2-nitro-9-oxo-5H-benzo[7]annulen-8(9H)-ylidene)-4-phenyl-1,3,4-thiadiazole2-carboxylate 19b. Yield: (0.33 g, 75\%); mp: $227-229^{\circ} \mathrm{C}$; buff crystals (EtOH/dioxan). IR $\left(\mathrm{KBr}, \mathrm{cm}^{-1}\right)$ : $v$ 1722, $1638(\mathrm{C}=\mathrm{O}) .{ }^{1} \mathrm{H}-\mathrm{NMR}\left(\mathrm{DMSO}-d_{6}\right): \delta 1.50\left(\mathrm{t}, J=7.0 \mathrm{~Hz}, 3 \mathrm{H}, \mathrm{CH}_{3}\right), 1.71-2.91\left(\mathrm{~m}, 6 \mathrm{H}, 3 \mathrm{CH}_{2}\right)$, $4.16\left(\mathrm{q}, J=7.1 \mathrm{~Hz}, 2 \mathrm{H}, \mathrm{CH}_{2}\right), 6.83-7.49(\mathrm{~m}, 8 \mathrm{H}, \mathrm{Ar}-\mathrm{H}),{ }^{13} \mathrm{H}-\mathrm{NMR}$ (DMSO- $\left.d_{6}\right): \delta 21.11,23.15,40.33$, $46.39,64.90,125.44,127.60,127.90,128.23,128.75,133.67,136.28,139.13,141.35,196.24$. MS $\mathrm{m} / \mathrm{z}(\%)$ : $438[\mathrm{M}+1](6), 437[\mathrm{M}]^{+}(30), 392(20), 364(15), 288$ (35), 203 (50), 125 (100), 77 (60). Anal. Calcd. for $\mathrm{C}_{22} \mathrm{H}_{19} \mathrm{~N}_{3} \mathrm{O}_{5} \mathrm{~S}$ (437.47): C, 60.40; H, 4.38; N, 9.61; S, 7.33. Found: $\mathrm{C}, 59.88 ; \mathrm{H}, 4.26 ; \mathrm{N}, 9.85 ; \mathrm{S}, 7.51$.

Ethyl 4,5-Dihydro-5-(5,6-dihydro-9-oxo-5H-benzo[7]annulen-8(7H)-ylidene)-4-p-tolyl-1,3,4-thiadiazole-2carboxylate 19c. Yield: $(0.29 \mathrm{~g}, 71 \%)$; mp: $192-195{ }^{\circ} \mathrm{C}$; gray crystals $(\mathrm{EtOH} / \mathrm{DMF}) . \mathrm{IR}\left(\mathrm{KBr}, \mathrm{cm}^{-1}\right)$ : v 1715, $1661(\mathrm{C}=\mathrm{O}) .{ }^{1} \mathrm{H}-\mathrm{NMR}\left(\mathrm{DMSO}-d_{6}\right): \delta 1.30\left(\mathrm{t}, J=6.9 \mathrm{~Hz}, 3 \mathrm{H}, \mathrm{CH}_{3}\right), 2.23\left(\mathrm{~s}, 3 \mathrm{H}, \mathrm{CH}_{3}\right), 2.46-2.92$ $\left(\mathrm{m}, 4 \mathrm{H}, 2 \mathrm{CH}_{2}\right), 3.53\left(\mathrm{q}, J=7.1 \mathrm{~Hz}, 2 \mathrm{H}, \mathrm{CH}_{2}\right), 4.27\left(\mathrm{~m}, 2 \mathrm{H}, \mathrm{CH}_{2}\right), 6.76-7.50(\mathrm{~m}, 8 \mathrm{H}, \mathrm{Ar}-\mathrm{H}) . \mathrm{MS} \mathrm{m} / \mathrm{z}$ (\%): $407[\mathrm{M}+1]^{+}(4), 406[\mathrm{M}]^{+}$(15), 333 (25), 315 (100), 242 (45), 158 (30), 91 (50). Anal. calcd. for $\mathrm{C}_{23} \mathrm{H}_{22} \mathrm{~N}_{2} \mathrm{O}_{3} \mathrm{~S}$ (406.50): $\mathrm{C}, 67.96 ; \mathrm{H}, 5.46 ; \mathrm{N}, 6.89 ; \mathrm{S}, 7.89$. Found: $\mathrm{C}, 67.52 ; \mathrm{H}, 5.28 ; \mathrm{N}, 7.06 ; \mathrm{S}, 8.13$.

Ethyl 4,5-Dihydro-5-(6,7-dihydro-3-nitro-9-oxo-5H-benzo[7]annulen-8(9H)-ylidene)-4-p-tolyl-1,3,4-thiadiazole2-carboxylate 19d. Yield: (0.37 g, 82\%); mp: $235-2375{ }^{\circ} \mathrm{C}$; pale yellow crystals (EtOH/DMF). IR (KBr, $\left.\mathrm{cm}^{-1}\right): v 1735,1670(\mathrm{C}=\mathrm{O}) .{ }^{1} \mathrm{H}-\mathrm{NMR}\left(\mathrm{DMSO}-d_{6}\right): \delta 1.35\left(\mathrm{t}, J=6.9 \mathrm{~Hz}, 3 \mathrm{H}, \mathrm{CH}_{3}\right), 1.91-2.61(\mathrm{~m}, 6 \mathrm{H}$, $\left.3 \mathrm{CH}_{2}\right), 3.28\left(\mathrm{~s}, 3 \mathrm{H}, \mathrm{CH}_{3}\right), 4.37\left(\mathrm{q}, J=7.1 \mathrm{~Hz}, 2 \mathrm{H}, \mathrm{CH}_{2}\right), 7.22-8.28(\mathrm{~m}, 7 \mathrm{H}, \mathrm{Ar}-\mathrm{H}),{ }^{13} \mathrm{H}-\mathrm{NMR}\left(\mathrm{DMSO}-d_{6}\right)$ : $\delta$ 13.35, 23.55, 25.90, 26.11, 38.23, 61.25, 116.32, 121.23, 125.75, 126.61, 127.67, 129.22, 135.13, 141.35, $143.43,148.20,148.60,155.62,162.20,185.32 . \mathrm{MS} m / z(\%): 452[\mathrm{M}+1]^{+}(12), 451[\mathrm{M}]^{+}(50), 360(15)$, 234 (61), 199 (36), 125 (29), 77 (100). Anal. calcd. for $\mathrm{C}_{23} \mathrm{H}_{21} \mathrm{~N}_{3} \mathrm{O}_{5} \mathrm{~S}$ (451.49): C, 61.01; H, 4.43; N, 9.54; S, 7.10. Found: C, 61.18; H, 4.69; N, 9.31; S, 7.31.

\subsubsection{General Procedure for the Preparation of Compounds 21a,b}

A mixture of the $\mathbf{1 a}, \mathbf{b}(5 \mathrm{mmol})$, mercaptoacetic acid (5 mmol) and $p$-tolunesulfonic acid (PTSA) in dry benzene $(50 \mathrm{~mL})$ was refluxed for $72 \mathrm{~h}$ and allowed to cool to room temperature then diluted with water $(30 \mathrm{~mL})$. The mixture was washed with saturated $\mathrm{NaHCO}_{3}$ followed by $0.1 \mathrm{~N} \mathrm{HCl}$ solution. The organic layer was separated and dried over anhydrous sodium sulfate, then evaporated under reduced pressure. The solid products were collected by filtration, washed with EtOH, dried and recrystallized from the prober solvent to afford compounds 21a,b.

3-((E)-6,7-Dihydro-5H-benzo[7]annulen-9-ylthio)propanoic acid 21a. Yield: $(0.21 \mathrm{~g}, 84 \%)$; mp: $193-195{ }^{\circ} \mathrm{C}$; White crystals (MeOH). IR (KBr, cm $\left.{ }^{-1}\right): v 1722(\mathrm{C}=\mathrm{O}) .{ }^{1} \mathrm{H}-\mathrm{NMR}\left(\mathrm{DMSO}-d_{6}\right): \delta 1.65\left(\mathrm{~m}, 2 \mathrm{H}, \mathrm{CH}_{2}\right), 1.96$ 
$\left(\mathrm{t}, J=6.7 \mathrm{~Hz}, 2 \mathrm{H}, \mathrm{CH}_{2}\right), 2.55-3.14\left(\mathrm{~m}, 6 \mathrm{H}, 3 \mathrm{CH}_{2}\right), 7.10-7.50(\mathrm{~m}, 5 \mathrm{H}, \mathrm{Ar}-\mathrm{H}+\mathrm{CH}=\mathrm{C}), 11.5(\mathrm{~s}, 1 \mathrm{H}, \mathrm{OH})$. MS $m / z(\%): 249[\mathrm{M}+1]^{+}(25), 248[\mathrm{M}]^{+}(100), 175$ (36), 143 (75). Anal. Calcd. for $\mathrm{C}_{14} \mathrm{H}_{16} \mathrm{O}_{2} \mathrm{~S}(248.34)$ : C, 67.71; H, 6.49; S, 12.91. Found: C, 67.55; H, 6.33; S, 13.17.

3-((E)-6,7-Dihydro-3-nitro-5H-benzo[7]annulen-9-ylthio)propanoic acid 21b. Yield: (0.35 g, 86\%); mp: 208-210 ${ }^{\circ} \mathrm{C}$; pale yellow crystals (EtOH). IR $\left(\mathrm{KBr}, \mathrm{cm}^{-1}\right): v 1735(\mathrm{C}=\mathrm{O}) .{ }^{1} \mathrm{H}-\mathrm{NMR}$ (DMSO- $\left.d_{6}\right): \delta 1.65$ $\left(\mathrm{m}, 2 \mathrm{H}, \mathrm{CH}_{2}\right), 1.69\left(\mathrm{t}, J=6.9 \mathrm{~Hz}, 2 \mathrm{H}, \mathrm{CH}_{2}\right), 2.55-2.90\left(\mathrm{~m}, 4 \mathrm{H}, 2 \mathrm{CH}_{2}\right), 3.14\left(\mathrm{t}, J=7.0 \mathrm{~Hz}, 2 \mathrm{H}, \mathrm{CH}_{2}\right)$, 7.33-8.50 (m, 4H, Ar-H + CH=C), 12.3 (s, 1H, OH). MS m/z (\%): 294[M + 1] $]^{+}(25), 293[\mathrm{M}]^{+}(100), 220$ (70), 188 (40), 143 (36). Anal. Calcd. for $\mathrm{C}_{14} \mathrm{H}_{15} \mathrm{NO}_{4} \mathrm{~S}$ (293.34): C, 57.32; H, 5.15; N, 477; S, 10.93. Found: C, 57.44; H, 5.04; N, 4.87; S, 11.16 .

\subsubsection{General Procedure for the Preparation of Compounds 22a,b}

To a solution of the appropriate mercaptopropanoic acid derivatives $\mathbf{2 1} \mathbf{a}, \mathbf{b}$ in benzene (thiophene free) $(100 \mathrm{~mL})$, phosphorus pentoxide $(1 \mathrm{mmol})$ was added. The resulting mixture was refluxed for $72 \mathrm{~h}$ and allowed to cool to room temperature then diluted with water $(30 \mathrm{~mL})$, and washed with a saturated $\mathrm{NaHCO}_{3}$ solution, then we separated the water and $\mathrm{HCl}$ was added. The solid products that formed were collected by filtration, washed with water, dried, and recrystallized from the ethanol to afford the newly tricyclic compounds 22a,b.

2,3-Dihydrothiopyran-4-one[b,f]-benzo[7]-9,10,11-trihydroanulene 22a. Yield: $(0.20 \mathrm{~g}, 86 \%)$; mp: 210-212 ${ }^{\circ} \mathrm{C}$; buff powder (EtOH). IR $\left(\mathrm{KBr}, \mathrm{cm}^{-1}\right): v 1695(\mathrm{C}=\mathrm{O}) .{ }^{1} \mathrm{H}-\mathrm{NMR}$ (DMSO- $\left.d_{6}\right): \delta 2.05(\mathrm{~m}$, $\left.2 \mathrm{H}, \mathrm{CH}_{2}\right), 2.26-2.50\left(\mathrm{~m}, 4 \mathrm{H}, 2 \mathrm{CH}_{2}\right), 2.80\left(\mathrm{~m}, 2 \mathrm{H}, \mathrm{CH}_{2}\right), 3.41\left(\mathrm{~m}, 2 \mathrm{H}, \mathrm{CH}_{2}\right), 7.01-7.50(\mathrm{~m}, 4 \mathrm{H}, \mathrm{Ar}-\mathrm{H}) . \mathrm{MS}$ $m / z(\%): 231[\mathrm{M}+1]^{+}(25), 230[\mathrm{M}]^{+}$(100), $214(36), 142$ (75). Anal. Calcd. for $\mathrm{C}_{14} \mathrm{H}_{14} \mathrm{OS}(230.33)$ : C, 73.01; H, 6.13; S, 13.92. Found: C, 72.79; H, 5.95; S, 14.26 .

2,3-Dihydrothiopyran-4-one[b,f]-3-nitrobenzo[7]9,10,11-trihydroanulene 22b. Yield: (0.23 g, 83\%); mp: 227-230 ${ }^{\circ} \mathrm{C}$; gray crystals (Dioxane). IR $\left(\mathrm{KBr} \mathrm{cm}^{-1}\right): v 1683(\mathrm{C}=\mathrm{O}) .{ }^{1} \mathrm{H}-\mathrm{NMR}$ (DMSO- $\left.d_{6}\right): \delta 2.15-2.70$ $\left.\left(\mathrm{m}, 6 \mathrm{H}, 3 \mathrm{CH}_{2}\right), 3.25\left(\mathrm{~m}, 2 \mathrm{H}, \mathrm{CH}_{2}\right), 4.07\left(\mathrm{t}, J=7.0 \mathrm{~Hz}, 2 \mathrm{H}, \mathrm{CH}_{2}\right), 7.71-8.47(\mathrm{~m}, 3 \mathrm{H}, \mathrm{Ar}-\mathrm{H}).\right) .{ }^{13} \mathrm{H}-\mathrm{NMR}$ (DMSO- $d_{6}$ ): $\delta 23.50,25.9,28.80,39.20,38.50,120.40,122.50,123.99,130.60,135.55,145.01,148.60,151.7$, 198.90. MS m/z (\%): $276[\mathrm{M}+1]^{+}(23), 275[\mathrm{M}]^{+}(100), 219$ (70), $186(40), 115$ (36), 63 (29). Anal. calcd. for $\mathrm{C}_{14} \mathrm{H}_{13} \mathrm{NO}_{3} \mathrm{~S}$ (275.32): $\mathrm{C}, 61.07 ; \mathrm{H}, 4.76 ; \mathrm{N}, 5.09 ; \mathrm{S}, 11.65$. Found: $\mathrm{C}, 60.93 ; \mathrm{H}, 4.63 ; \mathrm{N}, 5.21 ; \mathrm{S}, 11.89$.

\subsubsection{General Procedure for the Preparation of Compounds 24a,b}

A mixture of the compounds $22 \mathbf{a}$ and/or $22 \mathbf{b}(2 \mathrm{mmol})$, mercaptoacetic acid $(2 \mathrm{mmol})$ and PTSA ( $2 \mathrm{mmol}$ ) in dry benzene $(100 \mathrm{~mL})$ was refluxed for $24 \mathrm{~h}$ and allowed to cool to room temperature. Phosphorus pentoxide $(1 \mathrm{mmol})$ was then added and the resulting mixture was refluxed for additional $5 \mathrm{~h}$ and allowed to cool. The mixture was then diluted with water $(30 \mathrm{~mL})$, washed by saturated $\mathrm{NaHCO}_{3}$ and $0.1 \mathrm{~N} \mathrm{HCl}$. The organic layer was separated and dried over anhydrous sodium sulfate, then evaporated under reduced pressure. The solid products that formed were collected by filtration, washed with water, dried, and recrystallized from the prober solvent to afford compounds $24 \mathbf{a}, \mathbf{b}$.

2,3-Dihydrothiopyrano[3,2-b]thiopyran-4(8H)-one[d,f]benzo[7]anulen 24a. Yield: $(0.23 \mathrm{~g}, 86 \%)$; $\mathrm{mp}$ : 280-282 ${ }^{\circ} \mathrm{C}$; white crystal (EtOH/Dioxan). IR $\left(\mathrm{KBr}, \mathrm{cm}^{-1}\right): v 1692(\mathrm{C}=\mathrm{O}) .{ }^{1} \mathrm{H}-\mathrm{NMR}$ (DMSO- $\left.d_{6}\right)$ :

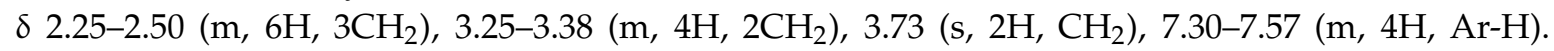
${ }^{13} \mathrm{H}-\mathrm{NMR}$ (DMSO- $d_{6}$ ): $\delta 24.1,24.9,35.50,38.40,38.90,126.00,126.7,128.01,128.7,132.0,135.17,138.99$, 196.03.MS m/z (\%): $301[\mathrm{M}+1]^{+}(23), 300[\mathrm{M}]^{+}(100), 211(50), 142$ (35). Anal. calcd. for $\mathrm{C}_{17} \mathrm{H}_{16} \mathrm{OS}_{2}$ (300.44): C, 67.96; H, 5.37; S, 21.35. Found: C, 67.84; H, 5.26; S, 21.66.

2,3-Dihydrothiopyrano[3,2-b]thiopyran-4(8H)-one[d,f]-3-nitrobenzo[7]anulene 24b. Yield: (0.31 g, 90\%); $\mathrm{mp}:>300{ }^{\circ} \mathrm{C}$; brown crystals (EtOH/DMF). IR $\left(\mathrm{KBr}, \mathrm{cm}^{-1}\right): v 1698(\mathrm{C}=\mathrm{O}) .{ }^{1} \mathrm{H}-\mathrm{NMR}$ (DMSO-d $)_{6}$ ): $\delta 2.30-2.78\left(\mathrm{~m}, 6 \mathrm{H}, 3 \mathrm{CH}_{2}\right), 3.27\left(\mathrm{t}, J=6.4 \mathrm{~Hz}, 2 \mathrm{H}, \mathrm{CH}_{2}\right), 3.33\left(\mathrm{t}, J=6.8 \mathrm{~Hz}, 2 \mathrm{H}, \mathrm{CH}_{2}\right), 3.89\left(\mathrm{~s}, 2 \mathrm{H}, \mathrm{CH}_{2}\right)$, 7.64-8.37 (m, 3H, Ar-H). MS m/z (\%): $346[\mathrm{M}+1]^{+}$(19), $345[\mathrm{M}]^{+}$(100), 299 (15), 257 (40), 209 (20), 
60 (25). Anal. Calcd. for $\mathrm{C}_{17} \mathrm{H}_{15} \mathrm{NO}_{3} \mathrm{~S}_{2}$ (345.44): C, 59.11; H, 4.38; N, 4.05; S, 18.56. Found: C, 58.97; $\mathrm{H}, 4.26 ; \mathrm{N}, 4.15 ; \mathrm{S}, 18.86$.

\subsubsection{General Procedure for the Preparation of Compounds 25a,b}

A mixture of the compound $24 \mathbf{a}$ and/or $24 \mathbf{b}(1 \mathrm{mmol})$ and hydrogen peroxide $(2 \mathrm{mmol})$ was refluxed for $24 \mathrm{~h}$ and allowed to cool to room temperature then diluted with water $(30 \mathrm{~mL})$. The solid products that formed were collected by filtration, washed with water, dried and recrystallized from the ethanol to afford compounds $25 \mathbf{a}, \mathbf{b}$.

2,3-Dihydro-dioxothiopyrano[3,2-b]dioxothiopyran-4(8H)-one[d,f]benzo[7]anulen 25a. Yield (0.23 g, 65\%); $\mathrm{mp}:>300{ }^{\circ} \mathrm{C}$; gray crystals (Dioxan). IR $\left(\mathrm{KBr}, \mathrm{cm}^{-1}\right): v 1689(\mathrm{C}=\mathrm{O}) .{ }^{1} \mathrm{H}-\mathrm{NMR}$ (DMSO- $\left.d_{6}\right): \delta 1.76$ $\left(\mathrm{m}, 2 \mathrm{H}, \mathrm{CH}_{2}\right), 2.15-2.30\left(\mathrm{~m}, 4 \mathrm{H}, 2 \mathrm{CH}_{2}\right), 2.63\left(\mathrm{~s}, 2 \mathrm{H}, \mathrm{CH}_{2}\right), 3.27-3.52\left(\mathrm{~m}, 4 \mathrm{H}, 2 \mathrm{CH}_{2}\right), 7.01-7.47(\mathrm{~m}, 4 \mathrm{H}$, Ar-H). MS m/z (\%): $366[\mathrm{M}+2]^{+}(3), 364[\mathrm{M}]^{+}(25), 246$ (30), 142 (70), 115 (100). Anal. Calcd. for $\mathrm{C}_{17} \mathrm{H}_{16} \mathrm{O}_{5} \mathrm{~S}_{2}$ (364.44): C, 56.03; H, 4.43; S, 17.60. Found: $\mathrm{C}, 55.76 ; \mathrm{H}, 4.28 ; \mathrm{S}, 18.04$.

2,3-Dihydro-dioxothiopyrano[3,2-b]dioxothiopyran-4(8H)-one[d,f]-3-nitrobenzo[7]anulene 25b. Yield (0.30 g, 75\%); mp: > $300{ }^{\circ} \mathrm{C}$; buff crystals (Dioxan). IR $\left(\mathrm{KBr}, \mathrm{cm}^{-1}\right): v 1695$ (C=O). ${ }^{1} \mathrm{H}-\mathrm{NMR}$ (DMSO-d ${ }_{6}$ ): $\delta 1.90\left(\mathrm{~m}, 2 \mathrm{H}, \mathrm{CH}_{2}\right), 2.15-2.30\left(\mathrm{~m}, 4 \mathrm{H}, 2 \mathrm{CH}_{2}\right), 2.53\left(\mathrm{~s}, 2 \mathrm{H}, \mathrm{CH}_{2}\right), 3.27-4.09\left(\mathrm{~m}, 4 \mathrm{H}, 2 \mathrm{CH}_{2}\right), 7.71-8.47$ $(\mathrm{m}, 3 \mathrm{H}, \mathrm{Ar}-\mathrm{H}) . \mathrm{MS} \mathrm{m} / \mathrm{z}(\%): 410[\mathrm{M}+1]^{+}(10), 409[\mathrm{M}]^{+}(100), 289$ (15), 187 (40). Anal. Calcd. for $\mathrm{C}_{17} \mathrm{H}_{15} \mathrm{NO}_{7} \mathrm{~S}_{2}$ (409.43): $\mathrm{C}, 49.87 ; \mathrm{H}, 3.69 ; \mathrm{N}, 3.42 ; \mathrm{S}, 15.66$. Found: $\mathrm{C}, 49.63 ; \mathrm{H}, 3.57 ; \mathrm{N}, 3.52 ; \mathrm{S}, 15.89$.

\subsection{Biological Evaluation}

\subsubsection{Antimicrobial Activity}

The ability to inhibit the growth of Gram-positive and Gram-negative bacteria, yeasts and filamentous fungi was observed using an overlay method [17].

\section{Sample Preparation}

All samples were dissolved in dimethyl sulfoxide (RFCL Limited, New Delhi, India) DMSO at $10 \mathrm{mg} / \mathrm{mL}$ concentration as shown in the Table 1 in comparison with different standard antibiotics. Antibiotic discs of Streptomycin (S) $(10 \mu \mathrm{g})$, Oxytetracycline (T) $(30 \mu \mathrm{g})$ and Tetracyciline (TE) $(30 \mu \mathrm{g})$ were used as positive controls for bacteria. Neomycin $(\mathrm{N})(30 \mu \mathrm{g})$, was used for fungi. The experiment was performed in triplicate.

\section{Strains and Media Used}

The common pathogenic and food spoilage microorganisms were selected for their relevance in bakery products and other food: the gram-positive bacteria; Bacillus subtilits NRRL-B-4219, Staphylococcus aureus ATCC 6538, Enterococcus faecalis ATCC 19433 and the gram negative bacteria; Escherichia coli ATCC 25922, Pseudomonas aeruginosa ATCC 9027, Proteus sp., yeasts such as Candida albicans ATCC 10231, fungi Aspergillus niger NRRL 2766 (equivalent to ATCC16888), and Aspergillus flavus ATCC 16883.

The bacteria were slanted on nutrient agar (Merck, Darmstadt, Germany), Yeast was slanted and mentioned on Sabaroud's agar medium (Lab M., Bury, Lancashire, UK) and the fungi was slanted and mentioned on the potato Dextrose Agar medium (Lab M Limited, Bury, Lancashire, UK). Mueller-Hinton agar (Lab M., Bury, Lancashire, UK) following the manufacturer's instructions was used for the assay.

\section{Bioassay}

The antibacterial screening was essentially by the well diffusion agar method [23,24]. The organisms were streaked in radial patterns on the agar plates. Plates were incubated under aerobic conditions at $37{ }^{\circ} \mathrm{C}$ and $28{ }^{\circ} \mathrm{C}$ for $24 \mathrm{~h}$ and $48 \mathrm{~h}$ for bacteria and fungi, respectively. In order to 
obtain comparable results, all prepared solutions were treated under the same conditions under the same incubated plates. All tests were performed in triplicate. Plates were examined for evidence of antimicrobial activities, represented by a zone of inhibition of the microorganism's growth around the holes, and diameters of clear zones were expressed in millimeters [25].

\subsubsection{Determination of Minimum Inhibitory Concentration (MIC)}

The in vitro minimum inhibitory concentration (MIC) of the synthesized compounds was determined by the agar well diffusion method. DMSO was used to prepare different concentrations ranging from 50 to $500 \mu \mathrm{g} / \mathrm{mL}$ by serial dilutions. The media were inoculated with $100 \mu \mathrm{L}$ of each of the $10^{6} \mathrm{cfu} / \mathrm{mL}$ bacterial and fungal strains, and the assay was applied by an agar well diffusion method. Blank DMSO was used as negative control. The plates were incubated aerobically in an incubator at $37^{\circ} \mathrm{C}$ for $24 \mathrm{~h}$ for bacterial strains and $25^{\circ} \mathrm{C}$ for $48 \mathrm{~h}$ for fungal strains. The MIC was taken as the lowest concentration in the series dilution that prevented bacterial growth.

\section{Conclusions}

An efficient one step method for the synthesis of substituted thiophene derivatives 9 from thioamides 4 and $\alpha$-haloketones has been performed. Reaction of 4 with $C$-acetyl- $N$-arylhydrazonoyl chlorides 14 and $C$-ethoxycarbonyl- $N$-arylhydrazonoyl chlorides 18 under basic conditions, afforded the corresponding 1,3,4-thiadiazoline derivatives 16 and 19, respectively. Benzosuberones 1 underwent condensation followed by cyclization to obtain tricyclic thiopyran-4 $(5 H)$-one derivatives and tetracyclic ring systems $\mathbf{2 4}$ and $\mathbf{2 5}$. The newly synthesized compounds showed to be active when tested as antimicrobial agents.

Acknowledgments: The project was financially supported by King Saud University, Vice Deanship of Research Chairs.

Author Contributions: The listed authors contributed to this work as described in the following. Osama I. Abd El-Salam, Aly S. Alsayed, Korany A. Ali, Abd El-Galil E. Amr gave the concepts of the work, interpreted the results and prepared the manuscript, Ahmed A. Abd Elwahab carried out the experimental part (this work is a part of his PhD thesis) and Hassan M. Awad tested the antimicrobial activities. All authors have read and approved the final manuscript.

Conflicts of Interest: The authors declare no conflict of interest.

\section{References}

1. Rida, S.M.; Habib, N.S.; Badawey, E.A.; Fahmy, H.T.; Ghozlan, H.A. Synthesis of novel thiazolo[4,5-d]pyrimidine derivatives for antimicrobial, anti-HIV and anticancer investigation. Pharmazie 1996, 51, 927-931. [CrossRef] [PubMed]

2. Bahashwan, S.A.; Fayed, A.A.; Ramadan, M.A.; Amr, A.E.; Al-Harbi, N.O. Androgen receptor antagonists and anti-prostate cancer activities of some newly synthesized substituted fused pyrazolo-, triazolo- and thiazolo-pyrimidine derivatives. Int. J. Mol. Sci. 2014, 15, 21587-21602. [CrossRef] [PubMed]

3. Abou-Ghalia, M.H.; Amr, A.E. Synthesis and investigation of a new cyclo-( $N^{\alpha}$-ipicolinoyl) pentapeptide of a breast and CNS cytotoxic activity and an ionophoric specifity. Amino Acids 2004, 26, 283-289.

4. Yadagiri, B.; Holagunda, U.D.; Bantu, R.; Nagarapu, L.; Kumar, C.G.; Pombala, S.; Sridhar, B. Synthesis of novel building blocks of benzosuberone bearing coumarin moieties and their evaluation as potential anticancer agents. Eur. J. Med. Chem. 2014, 79, 260-265. [CrossRef] [PubMed]

5. Nagarapu, L.; Yadagiri, B.; Bantu, R.; Kumar, G.; Pombala, S.; Nanubolu, J. Studies on the synthetic and structural aspects of benzosuberones bearing 2,4-thiazolidenone moiety as potential anti-cancer agents. Eur. J. Med. Chem. 2014, 71, 91-97. [CrossRef] [PubMed]

6. Tatsumi, M.; Groshan, K.; Blakely, R.D.; Richelson, E. Pharmacological profile of antidepressants and related compounds at human monoamine transporters. Eur. J. Pharmacol. 1997, 340, 249-258. [CrossRef]

7. Mutschler, E. Drug Actions: Basic Principles and Therapeutic Aspects; ISBN: 0-8493-7774-9; Medpharm Scientific Pub.: Stuttgart, Germany, 1995; p. 127. Retrieved 30 January 2013. 
8. Rostom, S.A.F.; El-Ashmawy, I.M.; Abd El Razik, H.A.; Badr, M.H.; Ashour, M.A. Design and synthesis of some thiazolyl and thiadiazolyl derivatives of antipyrine as potential non-acidic anti-inflammatory, analgesic and antimicrobial agents. Bioorg. Med. Chem. 2009, 17, 882-895. [CrossRef] [PubMed]

9. Ali, A.M.; Saber, G.E.; Mahfouz, N.M.; El-Gendy, M.A.; Radwan, A.A.; Hamid, M.A. Synthesis and three-dimensional qualitative structure selectivity relationship of 3,5-disubstituted-2,4-thiazolidinedione derivatives as COX2 inhibitors. Arch. Pharm. Res. 2007, 30, 1186-1204. [CrossRef] [PubMed]

10. Ouf, N.H.; Amr, A.E.; Sakran, M.I. Anticancer activity of some newly synthesized pyrano[2,3-d][1,2,3] triazine derivatives using 1-(7-hydroxy-2,2-dimethylchroman-6-yl)ethanone as synthon. Med. Chem. Res. 2015, 24, 1514-1526. [CrossRef]

11. Abd El-Salam, O.I.; Abou El-Ella, D.A.; Ismail, N.S.M.; Abdullah, M. Synthesis, docking studies and anti-inflammatory activity of some 2-amino-5,6,7,8-tetrahydroquinoline-3-carbonitriles and related compounds. Pharmazie 2009, 64, 147-155. [PubMed]

12. Abdel Salam, O.I.; Khalifa, N.M.; Said, S.A.; Amr, A.E. Synthesis and antimicrobial activities of some newly 2,4,6-tri-substituted pyridine derivatives. Res. Chem. Intermed. 2014, 40, 1147-1155. [CrossRef]

13. Amr, A.E.; Abd El-Salam, O.I.; Al-Omar, M.A. Synthesis of Chiral Macrocycles: I. Synthesis and Study of Cyclo ( $N^{\alpha}$-Dinicotinoyl)pentapeptide Candidates. Russ. J. Gen. Chem. 2015, 85, 1161-1166. [CrossRef]

14. Amr, A.E.; Ali, K.A.; Abdalla, M.M. Cytotoxic, antioxidant activities and structure activity relationship of some newly synthesized terpenoidaloxaliplatin analogs. Eur. J. Med. Chem. 2009, 44, 901-907. [CrossRef] [PubMed]

15. Ali, K.A.; Abdalghfar, H.S.; Mahmoud, K.; Ragab, E.A. Synthesis and antitumor activity of new poly-substituted thiophenes and 1,3,4-thiadiazoles incorporating 2,6-pyridine moieties. J. Heterocycl. Chem. 2013, 50, 1157-1164.

16. Ali, K.A.; Hosni, H.M.; Elngar, D.H.; Amr, A.E. Synthesis and reactions of 2-(phenylthiocarbamoyl)$\mathrm{N}$-(benzothiazol-2-yl)-3-phenyl-3-oxopropanamide with activated chloro-compounds. Phosphorus Sulfur Silicon 2014, 189, 1831-1840. [CrossRef]

17. Connell, S.R.; Tracz, D.M.; Nierhaus, K.H.; Taylor, D.E. Ribosomal protection proteins and their mechanism of tetracycline resistance. Antimicrob. Agents Chemother. 2003, 47, 3675-3681. [CrossRef] [PubMed]

18. Hinman, M.M.; Rosenberg, T.A.; Balli, D.; Black-Schaefer, C.; Chovan, L.E.; Kalvin, D.; Merta, P.J.; Nilius, A.M.; Pratt, S.D.; Soni, N.B.; et al. Novel antibacterial class: A series of tetracyclic derivatives. J. Med. Chem. 2006, 49, 4842-4856. [CrossRef] [PubMed]

19. Smith, P.A.S.; Berry, W.L. Some Exploratory Syntheses of Benzosuberans and Tetrahydrobenzazepinones and Some Related Diazoöxides. J. Org. Chem. 1961, 26, 27-36. [CrossRef]

20. Amr, A.E.; Mohamed, A.M.; Mohamed, S.F.; Abdel-Hafez, N.A.; Hammam, A.G. Anticancer activities of some newly synthesized pyridine, pyrane, and pyrimidine derivatives. Bioorg. Med. Chem. 2006, 14, 5481-5488. [CrossRef] [PubMed]

21. Dieckmann, W.; Platz, L. Ueber eineneue Bildungs weise von Osotetrazonen. Chem. Ber. 1905, 38, 2986-2990. [CrossRef]

22. Shawali, A.S.; Albar, H.A. Kinetics and mechanism of dehydrochlorination of N-aryl-Cethoxycarbonylformohydrazidoyl chlorides. Can. J. Chem. 1986, 64, 871-875. [CrossRef]

23. Williams, S.T.; Goodfellow, M.; Wellington, E.M.H.; Vickers, J.C.; Alderson, G.; Sneath, P.H.A.; Sackins, S.M.J.; Mortimer, A.M. A Probability Matrix for Identification of some Streptomycetes. J. Gen. Microbiol. 1983, 129, 1815-1830. [CrossRef] [PubMed]

24. Bonev, B.; Hooper, J.; Parisot, J. Principles of assessing bacterial susceptibility to antibiotics using the agar diffusion method. J. Antimicrob. Chemother. 2008, 61, 1295-1301. [CrossRef] [PubMed]

25. Cruickshank, R.; Duguid, J.P.; Marmion, B.P.; Swain, R.H.A. The practice of medicinal microbiology. In Medical Microbiology, 12th ed.; Churchill Livingstone: Edinburgh, UK, 1975; Volume 11, pp. 196-202.

Sample Availability: Samples of the compounds are not available from the authors.

(C) 2015 by the authors; licensee MDPI, Basel, Switzerland. This article is an open access article distributed under the terms and conditions of the Creative Commons by Attribution (CC-BY) license (http://creativecommons.org/licenses/by/4.0/). 